\title{
Is the Baekdudaegan "the Southern Appalachians of the East"? A comparison between these mountain systems, focusing on their role as glacial refugia
}

\author{
Mi Yoon Chung**, Jordi López-Pujol ${ }^{1, * *}$ and Myong Gi Chung* \\ Division of Life Science and the Research Institute of Natural Science, Gyeongsang National University, Jinju 52828, Korea \\ ${ }^{1}$ BioC-GReB, Botanic Institute of Barcelona (IBB-CSIC-ICUB), Passeig del Migdia s/n, Barcelona 08038, Spain \\ (Received 24 November 2016; Revised 12 December 2016; Accepted 17 December 2016)
}

\begin{abstract}
Based on genetic studies and palaeoecological surveys, the main Korean mountain range, the socalled "Baekdudaegan" (BDDG), has been recently suggested to be a major glacial refugium at the Last Glacial Maximum (LGM) for the boreal and temperate flora of northeastern Asia. On the basis of its shared role as a glacial refugium, and on a series of striking similarities in floristic richness and orographic features, the BDDG would constitute a sort of "eastern counterpart" of the Southern Appalachians. Given its floristic, biogeographic, and cultural value, the BDDG merits high priority for conservation.
\end{abstract}

Keywords: Baekdudaegan, conservation, glacial refugium, LGM, northeastern Asia, southeastern United States

The main mountain system of the Korean Peninsula, the socalled "Baekdudaegan" (hereafter the "BDDG") is a mountain range that stretches ca. $1,625 \mathrm{~km}$, from Mt. Baekdu in North Korea (the Democratic People's Republic of Korea, DPRK), in the border with China, to Mt. Jiri in South Korea (the Republic of Korea, ROK), at the southernmost tip of the Peninsula (Fig. 1). The BDDG has the particularity to be a watershed-crest-line; therefore, it is possible to travel from the beginning to the end along the ridgeline without crossing any rivers or streams, and it is popularly regarded as the "backbone" of the Peninsula (Choi, 2004). It is sometimes artistically represented as a crouching tiger, with Mt. Baekdu as the head, and the rest of the mountain as its twisting spine (Mason, 2011a). Deeply embedded within the spirituality of the nation, it is often viewed as a "sacred mountain", a concept mainly stemming from the Korean geomancy (pungsu) and Korean shamanism (mugyo/ shingyo) (Mason, 2011a). Despite being relatively unknown, the BDDG is certainly one of the longest mountain chains in Asia, and the longest in northeastern Asia. The BDDG has 14 subsidiary or associated mountain ranges (one jeonggan and 13 jeongmaeks), which form major river watersheds.
Based on phylogeographic and population genetics studies as well as on palaeoecological evidence (even though these kind of data are still scarce, particularly the latter), M. G. Chung and his colleagues (Chung et al., 2017) tested the hypothesis that the BDDG served as a major glacial refugium throughout the Pleistocene (see below for a brief explanation) and concluded that these mountains - as well as likely the 14 subsidiary mountain ranges-would have sustained large refugial areas for mainly (but not exclusively) boreal and temperate flora.

Despite its great significance as a glacial refugium at the Last Glacial Maximum (LGM) and probably at other glacial maxima, the BDDG is not directly comparable to the large refugial areas of the Northern Hemisphere (the northern Mediterranean Basin, southern US/northern Mexico, the SinoJapanese region, and the Qinghai-Tibetan Plateau) (Hewitt, 1996, 2000; Swenson and Howard, 2005; Soltis et al., 2006; Médail and Diadema, 2009; Qiu et al., 2011; Liu et al., 2012); these latter areas are much larger (sometimes even being almost entire floristic regions), sustain much larger and evolutionarydiverse floras, and are biogeographically more complex in

\footnotetext{
*Author for correspondence: mgchung@gnu.ac.kr

**Both authors contributed equally to this work, and should be considered co-first authors.
} 


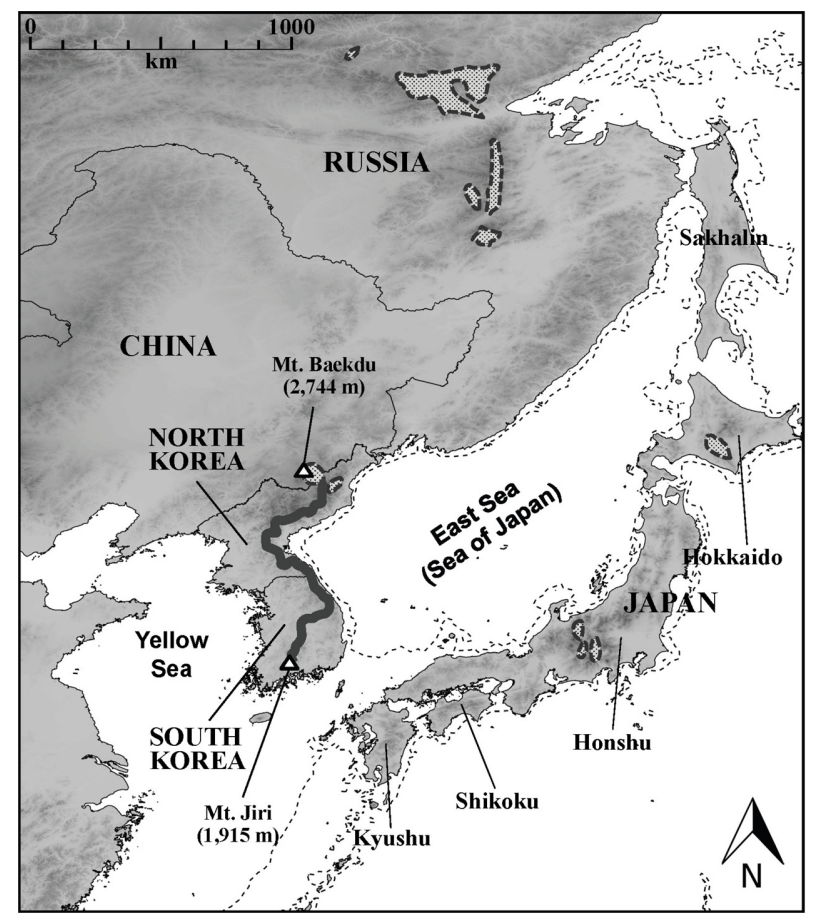

Fig. 1. The Baekdudaegan mountain system (where the main ridgeline is represented by a thick solid line) and its vicinity (including northeastern China, Russian Far East, and the Japanese Archipelago). Except for high-elevation mountains in DPRK (e.g., Mt. Baekdu known in China as Mt. Changbai) of 2,200-2,800 m above sea level (a.s.1.), high-elevation mountains in Honshu and Hokkaido in the Japanese Archipelago (although the glaciated areas in Japan are still debated) (Sawagaki and Aoki, 2011), and part of some mountain ranges in Russian Far East (such as the Stanovoy and Bureinsky ranges), the whole areas shown in Fig. 1 were never glaciated. Note that glaciers during the Last Glacial Maximum (LGM) are represented by dotted areas enclosed by dashed lines, and are drawn according to Zhou et al. (2011) for northeastern China, Kong and Watts (1993) for Korea, Ono et al. (2005) for Japan, and Velichko and Spasskaya (2002) for Russian Far East. The reconstructed LGM coastlines are represented by a thin dashed line.

terms of glacial survival (i.e., harboring multiple refugia or showing "refugia-within-refugia" scenarios) (e.g., Abellán and Svenning, 2014). The BDDG can be regarded, instead, as one of the main refugia within the Sino-Japanese region (see Fig. 1 in Qiu et al., 2011), and we believe that it is comparable to one of the main refuges within the southern US/northern Mexico large refugial area: the Southern Appalachians of eastern North America (Fig. 2).

In this review, after summarizing genetic and palaeoecological evidences that support the role of the BDDG as a Pleistocene refugium, we present the analogy between the BDDG and the Southern Appalachians, which is based on mountain features (in terms of length, orientation, altitude, and latitude), plant diversity, palaeoecology, and genetic diversity. We close this study by emphasizing the conservation of this mountain chain and providing some suggestions for establishing priorities for its long-term preservation.

\section{Role of the BDDG as a Glacial Refugium: Genetic and Palaeoecological Data}

Despite phylogeographic studies focusing on the Peninsula (or those in which Korean populations are included) are still few compared to neighboring areas such as China or Japan, their results were generally consistent with the "southern richness" vs. "northern purity" paradigm (Hewitt, 2000; Hu et al., 2009) and the "Expansion-Contraction (E-C)" model of Quaternary demography (Provan and Bennett, 2008). For the great majority of studies (about a dozen in total, focused on boreal, boreal-temperate, and temperate species), Korean populations harbored higher genetic diversity than more northerly-located populations (with latitudinal decreases of genetic-variation for some cases), ancestral haplotypes, and/or significant amounts of unique haplotypes/alleles (Chung et al., 2017).

When compiling the more "classical" studies on genetic diversity/structure, those plants whose distribution in Korea is mostly centered in the BDDG (i.e., with most of their populations occurring on the main ridge of the BGGD or its immediate vicinity) shared a clear pattern of high withinpopulation $\left(\% P=46.0 ; A=1.72 ; H_{\mathrm{e}}=0.159\right.$ with allozymes $)$ and low to moderate among-population genetic variability $\left(F_{\mathrm{ST}}\right.$ $=0.175$ ) (Table 1 in Chung et al., 2017). Although the number of studies is not large (16 in total), this trend seems to be clear given that studied species include both boreal and temperate, both widespread and range-restricted species, and all life-forms (herbs, shrubs, and trees). These average values, in addition, are higher than reference values for plants (Table 1). Notably, populations of several species located in jeongmaeks also harbored high generic variability, including Cimicifuga dahurica, Iris odaesanensis, Lilium cernuum, L. distichum, Megaleranthis saniculifolia, Oreorchis patens, Sedum kamtschaticum, and S. ussuriense (see Chung et al., 2017).

Palaeovegetation reconstructions for the Peninsula are largely contradictory probably because they mostly rely on climate models (that are often very different among themselves). Roughly four different palaeovegetation schemas have been suggested: almost total dominance of non-forest vegetation (Adams and Faure, 1997; Zheng et al., 2007), boreal forests (Hope et al., 2004; Woillez et al., 2011), treeless vegetation combined with boreal forests (Harrison et al., 2001), 


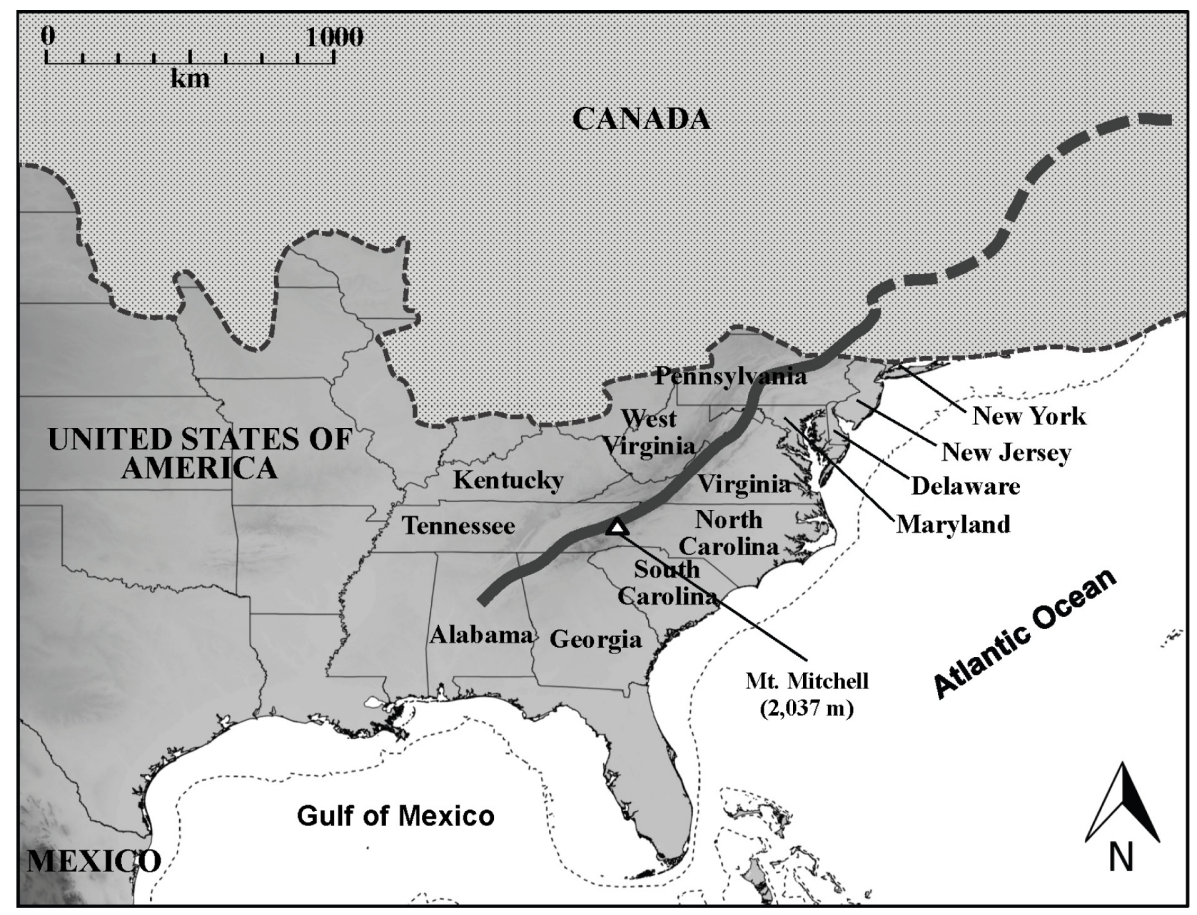

Fig. 2. The Southern Appalachians and its vicinity (its main ridge is approximately represented by a thick solid line). It should be noted that the Southern Appalachians have multiple ridgelines (in contrast to the single ridgeline that characterizes the Baekdudaegan [BDDG]) and also includes various intermontane valleys. The Appalachians sensu lato are much longer (ranging from central Alabama to Newfoundland in Canada, with about 2,400 km). The definition followed by us for the "Southern Appalachians" can be approximately equated to the sum of "Southern" and "Central Appalachians" according to the Geological Society of America (Hatcher et al., 2007), and it is also highly coincident with the Appalachian Mountain Bird Conservation Region (AMBCRP, 2005). The "Northern Appalachians" are represented by a thick dashed line. The dotted area enclosed by a dashed line represents the extent of continental ice sheet at the Last Glacial Maximum (LGM) (French and Millar, 2014). The reconstructed LGM coastlines are represented by a thin dashed line.

or a mixture of boreal and temperate forests (the former dominant in North Korea and the latter in South Korea) (PetitMaire and Bouysse, 2000; Prentice et al., 2011). Although not all these reconstructions agree with genetic data, the highresolution (and enough long) pollen records unambiguously support the glacial refugium scenario: the 11 pollen sequences available to date for Korea point towards the occurrence of large forest extensions along the BDDG mountain range, at least in its southern and central section; non-forest vegetation (arctic-alpine tundra or cold steppe) was probably confined only to the glacial and periglacial areas (Chung et al., 2017).

Based on both genetic and paleoecological data, therefore, the BDDG was likely a major "southern" glacial refugium (sensu Stewart et al., 2010) for the Asian boreal flora for most of its length, whereas large refugial areas for the temperate vegetation would have been limited to its southernmost section - albeit small refugial areas (i.e., "cryptic northern" refugia sensu Stewart et al., 2010, or "microrefugia" sensu Rull, 2009) probably occurred further north. Factors ensuring enough humidity even during the driest phases of the Quaternary (orographic precipitation, closeness to the sea) and the large altitudinal gradients of the BDDG (that enabled plants' vertical migrations) would have contributed to the role played by these mountains in the persistence of the Korean native flora throughout the Pleistocene.

\section{Comparison of the BDDG with the Southern Appalachians}

\section{Similarities in mountain features, plant diversity, ecology, and palaeoecology}

The Southern Appalachians are the main mountain range of the southeastern US, running north to south, in an analogous way to the BDDG (Fig. 2). Although the precise boundaries varies depending on the multiple definitions that exist for these mountains, we have taken one of the most classical ones (e.g., Rankin, 1975) that considers that the Southern Appalachians stretch from central Alabama to southern New York (Fig. 2) and that approximately coincide with the cultural region of "Appalachia" (Edwards et al., 2006; ARC, 2016). Following 
this definition, the Southern Appalachians are also highly comparable to the BDDG in terms of length (ca. 1,500 km vs. $1,625 \mathrm{~km}$ ), latitude (ca. $33-43^{\circ} \mathrm{N}$ vs. $35-42^{\circ} \mathrm{N}$ ), and average elevation (both ranges are composed by low and mediumelevation mountains rarely exceeding 2,000 $\mathrm{m}$ above sea level).

Interestingly, the BDDG and the Southern Appalachians have also similar floristic richness, with over 1,500 taxa for the former (Lim, 2003) and ca. 1,400 taxa for the latter (HBS, 2016). In addition to the species richness, both mountain systems have also comparable vegetation (mainly mixed and temperate forests), which is not surprising given the wellknown floristic similarities between East Asia and eastern North America (e.g., Boufford and Spongberg, 1983; Wen, 1999). The BDDG is mainly covered by temperate deciduous forests (Quercus mongolica and Pinus densiflora as dominant species) in its southern and central sections, with mixed forests in its northern one (Abies/Betula/Pinus/Tilia/Ulmus) (Yi, 2011). The Southern Appalachians are at present dominated by temperate deciduous forests, mainly Quercus spp. forests, but also Quercus-Pinus forests in its southern tip (sometimes interpreted as transitional between the deciduous forests and the subtropical broadleaved evergreen forests) and mixed forests (Acer/Betula/Fagus/Pinus/Tsuga) in its northern tip (as transitional between deciduous and boreal forests) (Braun, 1950; Dyer, 2006).

Being considered a prime refugial area for both the flora and fauna of North America (Davis, 1981; Delcourt and Delcourt, 1981; Soltis et al., 2006), the Southern Appalachians were probably dominated by boreal (such as those of Pinus banksiana) and/or mixed forests, with temperate deciduous forests absent or only occurring in the southernmost areas (Adams and Faure, 1997; Graham, 1999; Jackson et al., 2000; Williams et al., 2000; Woillez et al., 2011); alternatively, these mountains would have been dominated by temperate forests with coniferous ones located in its northernmost section (Prentice et al., 2011). Tundra would have probably covered the northern tip of this mountain range (just south of the Laurentide ice-sheet) but also occurred at higher elevations at lower latitudes (Woodcock and Wells, 1990; Graham, 1999). The palaeovegetation sketch for the Southern Appalachians is, therefore, very close to that suggested for the BDDG.

\section{Dissimilarities in palaeoecology and palaeovegetation}

In spite of the remarkable similarities between these two mountain systems, they also show some differences that largely concern palaeoecology. The most significant difference, perhaps, is that the southern margin of the massive Laurentide ice-sheet was located as low as latitudes $41-42^{\circ} \mathrm{N}$ in Pennsylvania (i.e., the northernmost tip of the Southern Appalachians was glaciated) (Fig. 2). In contrast, although the northernmost tip of the BDDG was glaciated, glaciers were small and limited to Mt. Baekdu and some close high mountains. Further north, the nearest ice-sheets were located at about $50^{\circ} \mathrm{N}$ in Khabarovsk Krai, in Russian Far East (Fig. 1). In other words, whereas the boreal forests of the northern section of the Southern Appalachians were interrupted by the Laurentide ice-sheet (with a narrow band of tundra just south of the ice-sheet), those of the northern part of the BDDG continued up to latitudes of $50^{\circ} \mathrm{N}$ (Harrison et al., 2001; Prentice et al., 2011) or even $55^{\circ} \mathrm{N}$ (Woillez et al., 2011). For example, pollen data from a site located at latitude $43^{\circ} \mathrm{N}$ in Khabarovsk Krai suggest the presence of tundra mixed with boreal trees (Mokhova et al., 2009), whereas in Primorsky Krai, in a couple of sites at latitude ca. $43^{\circ} \mathrm{N}$, boreal vegetation dominated by Betula (accompanied by Larix, Picea, and Pinus) would have occurred (Cao et al., 2015).

An additional difference between the Southern Appalachians and the BDDG is that the southern end of the Appalachians is surrounded by much more extensive piedmont and coastal plains, areas that could have served as refugia for the warmeradapted species (whose modern populations are now located at higher elevations within the Southern Appalachians) (J. L. Hamrick, pers. comm.; M. G. Chung., pers. obs.). There is rather strong evidence that Pinus banksiana and P. resinosa and other northern species (Picea spp.) occurred at low elevations (Coastal Plain in North Carolina and upper Piedmont of northern Georgia) (e.g., Jackson et al., 2000) and that more thermophilic species such as the monocot Trillium cuneatum (presently a Piedmont and lower elevation Appalachian species, associated with warm-temperate forests) occurred primarily in Gulf Coast refugia (Gonzales et al., 2008). This type of warm-temperate vegetation was likely absent in the continental Korean Peninsula.

\section{Similarities in genetic diversity}

As introduced above (i.e., see the section "Role of the BDDG as a glacial refugium: genetic and palaeoecological data"), levels of genetic diversity decrease with increasing latitudes for most plant species of northeastern Asia-thus fitting the southern richness vs. northern purity paradigm and pointing out the role of the BDDG as a refugium.

In the Southern Appalachians, many plant species with boreal and temperate affinities survived and expanded 
northwards with the deglaciation, also leaving a signal on their genomes (Hewitt, 2004; Soltis et al., 2006). There are numerous examples of high levels of genetic diversity in the Southern Appalachians compared to more northern conspecific populations, with several cases showing a south-to-north decrease of genetic diversity. Here, we limit only to two wellstudied examples in the Southern Appalachians, the two perennial herbs Asclepias exaltata (Broyles, 1998) and Helonias bullata (Godt et al., 1995). Broyles (1998) compared allozyme variation between 19 northern populations of $A$. exaltata occurring in previously glaciated regions in North America and 18 ones growing in the Pleistocene refugium of the Southern Appalachians and found a significant decrease in population-level allozyme diversity across a south-to-north transect. In a similar study, Godt et al. (1995) conducted allozyme analyses of 15 populations sampled across the range of $H$. bullata (that occur in wetlands usually associated with temperate or cool-mixed forests in New Jersey, Virginia, and the Southeastern Appalachians); as for A. exaltata, the authors found a significant latitudinal trend in genetic diversity (i.e., a decrease in genetic diversity with increasing latitudes). The trend exemplified by these two studies fits the southern richness vs. northern purity paradigm and the E-C model and is exactly what we would expect for plant taxa occurring in N-S oriented mountain ranges. Plant populations in the Southern Appalachians should be regarded as relictual ones from the last glacial epoch and would have been the source for the postglacial recolonization of more northerly sites. However, the violation of the southern richness vs. northern purity paradigm (i.e., more genetic diversity in formerly glaciated northern regions) has been reported for the conifer Pinus resinosa (Walter and Epperson, 2001) and the North American orchids Cypripedium parviflorum (Wallace and Case, 2000), Cypripedium reginae (Kennedy and Walker, 2007), and Isotria medeoloides (Stone et al., 2012). The authors have attributed this intriguing outcome to (i) presence of a periglacial or cryptic northern refugia that provided abundant northern habitats for these species, (ii) random genetic drift caused by decimation of southern populations during glaciations or as consequence of the Holocene warming, (iii) admixture of lineages arriving from different refugia and/or (iv) complex migration routes.

Although for northeastern Asia there are no congeneric comparisons between species occurring on the BDDG and more northern congeners (i.e., occurring in northeastern China and/or in Russian Far East), many of such south-north congeneric comparisons are available in North America. These studies have consistently revealed lower genetic variability in northern species compared to their southern congeners (Bayer et al., 1987; Whitkus et al., 1987; Lewis and Crawford, 1995; Hannan and Orick, 2000), in agreement with the refugial role of the Southern Appalachians. For example, Lewis and Crawford (1995) found that the more southerly species of each of several closely related species of Polygonella pairs consistently had higher gene diversity, regardless of life span (annuals vs. perennials) and floral traits (hermaphroditic vs. dioecious, etc.). The authors speculated that several endemic taxa occupying southern Pleistocene refugia maintain higher levels of genetic diversity because of larger population sizes and greater stability during the last glacial epoch. The results of Iris in North America are also illustrative; Hannan and Orick

Table 1. Comparison of allozyme-based genetic diversity and genetic differentiation $\left[F_{\mathrm{ST}}\right.$ or Nei's $\left.(1973) G_{\mathrm{ST}}\right]$ for species occurring mainly on the Baekdudaegan with rare plants in the southeastern United States and species having similar life history traits.

\begin{tabular}{|c|c|c|c|c|c|c|c|c|}
\hline Species & $\% P_{\mathrm{p}}$ & $\% P_{\mathrm{s}}$ & $A_{\mathrm{p}}$ & $A_{\mathrm{s}}$ & $H_{\mathrm{ep}}$ & $H_{\mathrm{es}}$ & $\begin{array}{c}G_{\mathrm{ST}} \\
\text { (or } F_{\mathrm{ST}} \text { ) }\end{array}$ & Ref. $^{b}$ \\
\hline Species occurring mainly in the Baekdudaegan ${ }^{\mathrm{a}}\left(N_{\mathrm{s}}=16 ; N_{\mathrm{p}}=16\right)$ & 46.0 & 64.3 & 1.72 & 2.20 & 0.159 & 0.193 & 0.175 & 1 \\
\hline Rare plants in the southeastern US $\left(N_{\mathrm{s}}=52 ; N_{\mathrm{p}}=52\right)$ & 33.3 & 46.7 & 1.53 & 1.87 & 0.100 & 0.123 & 0.187 & 2 \\
\hline Plants with a narrow distribution $\left(N_{\mathrm{s}}=101 ; N_{\mathrm{p}}=115\right)$ & 30.6 & 45.1 & 1.45 & 1.83 & 0.105 & 0.137 & na & 3 \\
\hline Short-lived herbaceous perennials $\left(N_{\mathrm{s}}=152 ; N_{\mathrm{p}}=159\right)$ & 28.0 & 41.3 & 1.40 & 1.70 & 0.096 & 0.116 & 0.233 & 4 \\
\hline Plants with outcrossing-animal breeding system $\left(N_{\mathrm{s}}=172 ; N_{\mathrm{p}}=164\right)$ & 35.9 & 51.1 & 1.54 & 1.99 & 0.124 & 0.167 & 0.197 & 4 \\
\hline Endemic plants $\left(N_{\mathrm{s}}=81 ; N_{\mathrm{p}}=100\right)$ & 26.3 & 40.0 & 1.39 & 1.80 & 0.063 & 0.096 & 0.248 & 4 \\
\hline All plants $\left(N_{\mathrm{s}}=725 ; N_{\mathrm{p}}=725\right)$ & 35.1 & 52.2 & 1.53 & 1.99 & 0.116 & 0.153 & 0.225 & 5 \\
\hline
\end{tabular}

$\% P$, percentage of polymorphic loci; $A$, mean number of alleles per locus; $H_{\mathrm{e}}$, Hardy-Weinberg expected heterozygosity or genetic diversity; $G_{\mathrm{ST}}$ (or $F_{\mathrm{ST}}$ ), measures of among-population differentiation. The subscript "s" indicates species' (or pooled samples) values, while the subscript "p" indicates population means. $N_{\mathrm{s}}$, number of species compiled; $N_{\mathrm{p}}$, number of populations compiled; na, not available.

${ }^{a}$ Only species with most of their populations in Korea occurring in the Baekdudaegan (in its main ridge or in the peripheral areas to the main ridge).

'Source references: 1, Chung et al. (2017); 2, Godt and Hamrick (2001); 3, Godt and Hamrick (1998a) and updated in Wang et al. (2004); 4, Hamrick and Godt (1989); 5, Godt and Hamrick (1998b). 
(2000) found that levels of genetic diversity in I. cristata, a species that is primarily occupying unglaciated regions in the Southern Appalachians, were considerably higher than those found for I. lacustris, which occurs in the glaciated areas of the Great Lakes shorelines. It may be of interest to note that levels of genetic variation of I. cristata are comparable to those found in another Iris species, I. odaesanensis, that is primarily distributed in the BDDG $\left[H_{\mathrm{e}}=0.199\right.$ for $I$. cristata (Hannan and Orick, 2000) vs. 0.158 for Iris odaesanensis (Chung et al., 2015)].

Regarding heterospecific comparisons, Godt and Hamrick (2001) summarized the genetic diversity and structure for 52 rare seed plant taxa from the southeastern US. The authors speculated that these taxa would have more genetic diversity compared to endemic plants overall, because southeastern US plant species are located within or close to glacial refugia (such as the Southern Appalachians and those along the Gulf Coast) (Soltis et al., 2006); such location would have allowed plants to experience less genetic drift and higher rates of gene flow than species located close to glacial boundaries. Consistent with this expectation, Godt and Hamrick (2001) found that populations of rare southeastern US plants had significantly greater values for $\% P, A$, and $H_{\mathrm{e}}$ than those reported for endemics $\left(\% P=33.3\right.$ vs. $26.3, A=1.53$ vs. 1.39 , and $H_{\mathrm{e}}=$ 0.100 vs. 0.063 ) (Table 1). Although the genetic variability of southeastern US rare plants is somewhat smaller than those for species native to the BDDG $\left(\% P=46.0, A=1.72, H_{\mathrm{e}}=\right.$ 0.159) (Table 1), we should take into account that the species compiled by Godt and Hamrick (2001) are range-restricted and not all are exclusively circumscribed to the Southern Appalachians or to other southeastern US refugia.

\section{Conservation Value of the BDDG}

The BDDG should be a high priority for conservation given its role as glacial refugium for the boreal and temperate flora of northeastern Asia and because it is the major center of plant diversity of the Korean Peninsula. As stated above, the ROK section of the BDDG harbors ca. 1,500 plant species, i.e., up to one third of the total vascular flora estimated for the Korean Peninsula (4,662) (Kim, 2006); of these, at least one hundred taxa (Choi, 2004; Cho and Chun, 2015) are endemic to Korea (i.e., ca. one third of all the endemic species to the Peninsula, 339 taxa) (Kim et al., 2009). Notably, the six genera traditionally regarded as endemic to Korea (Abeliophyllum, Coreanomecon, Echinosophora, Hanabusaya, Megaleranthis, and Pectactina) (Kim, 2006; Kim et al., 2009) occur totally or partially within the BDDG and its vicinity. Finally, it should also be noted that most of the legally protected plant species of Korea have their populations within the BDDG mountain range (Kang et al., 2010), confirming its role as a "hotspot" for plant conservation. The BDDG is also rich in ecosystems; despite that these mountains are mostly covered by temperate deciduous forests (dominated by Quercus mongolica and Pinus densiflora), up to 49 plant communities have been identified (Lee et al., 2013), including those typical of grasslands and wetlands; even two wetland sites have achieved international recognition as Ramsar sites (Odaesan National Park Wetlands and The High Moor, Yongneup of Mt. Daeam). A recent study has identified the BDDG as the most significant region for maintaining biodiversity of ROK, based on a combination of indicators that include plant and animal diversity, soils, scenery, and habitat representativeness and connectivity (Lee et al., 2015).

In addition to its ecological value, the BDDG also merits the highest level of protection because of its central role in the Korean culture and spirituality, which would have contributed in turn to keep these mountains relatively pristine until 1950s1960s (Jung et al., 2005). The BDDG constitutes a holy mountain system for almost all the religions and beliefs present in Korea (Shamanism, Buddhism, Daoism, Neo-Confucianism, and even Christianism) (see also Choi, 2004; Mason and Chung, 2008; Mason, 2011a, 2011b). The mountains are plenty of sacred or religious sites and objects (e.g., nearly one-fifth of the Buddhist temples of ROK are located in the BDDG) (Cho and Chun, 2015) as well as many other cultural assets. The concerted conservation of culture and biodiversity is gaining importance in recent times, mainly due to the recognition of the concept of "cultural landscapes" and its role in the conservation of biodiversity about two decades ago (Lennon, 2006; Schaaf and Lee, 2006). The creation of the Alliance of Religions and Conservation in 1986 has also greatly contributed to create positive synergies among the preservation of sacred sites, the sustainable development of local communities (by initiatives such as ecotourism), and the conservation and management of natural resources (Dudley et al., 2005; Verschuuren et al., 2010).

Fortunately, large parts of the ROK section of the BDDG are protected, mainly by the network of protected areas (PAs). In addition to seven national and two provincial parks, over 170 PAs of other types contribute altogether to preserve 2,274 $\mathrm{km}^{2}$ (Miller and Kim, 2010). The setting up of the BDDG Mountains Reserve (BMR) in 2005 integrated these areas, in addition to adding $360 \mathrm{~km}^{2}$ of newly protected land. However, conservation problems still persist, which include: (i) a clearly insufficient protection of the DPRK section of the BDDG by 
the DPRK network of PAs; the ROK part of the BDDG, although better covered, has still some gaps (e.g., in some sections the BMR is just a few hundreds of meters wide); (ii) management flaws, that in ROK that are related to weak engagement with local communities and lack of coordination of biodiversity and cultural resources (Heo et al., 2010); in DPRK, management problems are much larger and likely most PAs are just "paper parks" (McKinnon and Xie, 2008); (iii) deforestation, which is still occurring - despite limited - in the ROK part; in DPRK, although official reliable data are not available, deforestation would have occurred probably at a large-scale based on satellite imagery (Engler et al., 2014; Kang and Choi, 2014); (iv) lack of scientific knowledge in the DPRK section of the mountains; and (v) lack of cooperation between DPRK and ROK. In addition, the recent touristic development of the BDDG represents a growing problem in its ROK section and, for example, some degradation has been reported at the "BDDG hiking trail" (e.g., Kwon and Lee, 2003; Kwon et al., 2004; Cho and Chun, 2015). The BDDG hiking trail, $735 \mathrm{~km}$ long and established as a trail since the 1980s, constitutes, interestingly, another singular analogy with the Appalachians, which hold one of the longest and most celebrated hiking trails of the world (it attracts 2-3 million visitors yearly) (APC, 2016). Although much longer (over 3,500 km from Georgia to Maine) and somewhat older (it was conceived in 1921 and completed in 1937), the Appalachian Trail has also a deep spiritual dimension (Redick, 2009; Bratton, 2012). As for the BDDG trail, the Appalachian one is also peppered with many archaeological, cultural, and spiritual sites, including those related to native Americans, the European settlers, or with the American Civil War (Marshall, 1998; Lillard, 2002; Joyner, 2016).

\section{Conclusions and Conservation Suggestions}

(1) Both genetic and palaeoecological studies (though still limited) clearly suggest that the BDDG mountain range was a major refugial area for the boreal and temperate flora. These mountains should, thus, be added to the list of the well-known East Asian Pleistocene refugia (e.g., the Hengduan Mountains, the central China Mountains, or the Nanling Mountains) (Qiu et al., 2011).

(2) The BDDG would constitute a sort of "eastern counterpart" of the Southern Appalachians on the basis of its shared role as a glacial refugium (for boreal and temperate elements) and a series of striking similarities in floristic richness (number of species), ecology, and orographic features (length, orientation, altitude, and latitude).
(3) The rich plant diversity of the BDDG (with its associated ecosystem services) as well as its role as a Pleistocene glacial refugium stress the need to ensure effective and integral conservation of this mountain range. This need is even greater because refugia of the past would be refugia in the future (Bhagwat and Willis, 2008; Médail and Diadema, 2009). Conservation measures should include: (i) enlarging the current BMR to cover the mid and lowaltitude peripheral areas of the main ridge of the BDDG, as well as the jeonggan and jeongmaeks; these "branches" would also have had a significant role for the glacial survival of the Korean native flora according to genetic data (see Chung et al., 2017); (ii) setting new PAs in DPRK and improving the management of the existing ones to meet their conservation goals; (iii) promoting cooperation between DPRK and ROK in conserving not only the BDDG but the whole Korean plant resources, which can be a way to improve diplomatic relations (Raven, 2013; Kim and Ali, 2016); this cooperation would allow extending the current uninterrupted preserved area from the Demilitarized Zone to Mt. Baekdu, while further regional transboundary initiatives would integrate the BDDG into an envisaged "Ecological Corridor of Northeast Asia" (e.g., Hayes, 2010). Such "mega" corridor, which was one of the recommendations adopted at the IUCN 2012 World Conservation Congress (IUCN, 2012), would integrate the BDDG, Mt. Changbai in China, Tumen River basin, and the mountain system of Sikhote-Alin in Russian Far East; and (iv) conducting more research, which is needed for a better understanding of the role of the main Korean mountain systems (the BDDG plus its branches) in the diversity and evolution of the regional plant diversity; research efforts should be focused in the DPRK, as it still constitutes a sort of "black hole" of botanical knowledge within the regionwe are not aware of any published genetic or palaeoecological study concerning DPRK native plants.

\section{Acknowledgments}

This research was supported by the Basic Science Research Program through the National Research Foundation of Korea (NRF) funded by the Ministry of Education (NRF2013R1A1A2063524 and NRF-2013R1A1A3010892 to M.G.C. and M.Y.C., respectively).

\section{Literature Cited}

Abellán, P. and J.-C. Svenning. 2014. Refugia within refugia: patterns in endemism and genetic divergence are linked to Late 
Quaternary climate stability in the Iberian Peninsula. Biological Journal of the Linnean Society 113: 13-28.

Adams, J. M. and H. Faure. 1997. Review and atlas of palaeovegetation: preliminary land ecosystem maps of the world since the Last Glacial Maximum. Oak Ridge National Laboratory, Oak Ridge. Retrieved Oct. 21, 2016, available from http:// www.esd.ornl.gov/projects/qen/adams1.html.

AMBCRP (Appalachian Mountains Bird Conservation Region Partnership). 2005. Appalachian Mountains Bird Conservation Initiative: concept plan. Retrieved Oct. 21, 2016, available from http://www.acjv.org/documents/bcr28_concept_plan.pdf.

APC (Appalachian Trail Conservancy). 2016. History of the trail. Retrieved Oct. 21, 2016, available from https://www.appalachiantrail.org/promo/75th-anniversary/at-history

ARC (Appalachian Regional Commission). 2016. Map of the Appalachian Region. Retrieved Oct. 21, 2016, available from https:// www.arc.gov/appalachian_region/MapofAppalachia.asp.

Bayer, R. J., J. C. La Duke and D. J. Crawford. 1987. Isozyme variation in Trillium nivale (Liliaceae). Canadian Journal of Botany 65: 2250-2254.

Bhagwat, S. A. and K. J. Willis. 2008. Species persistence in northerly glacial refugia of Europe: a matter of chance or biogeographical traits? Journal of Biogeography 35: 464-482.

Boufford, D. E. and S. A. Spongberg. 1983 Eastern Asian-eastern North American phytogeographical relationships: a history from the time of Linnaeus to the twentieth century. Annals of the Missouri Botanical Garden 70: 423-439.

Bratton, S. P. 2012. The Spirit of the Appalachian Trail: Community, Environment, and Belief on a Long-Distance Hiking Path. The University of Tennessee Press, Knoxville 284 pp.

Braun, E. L. 1950. Deciduous Forests of Eastern North America. Blakiston Co., Philadelphia, PA, 596 pp.

Broyles, S. B. 1998. Postglacial migration and the loss of allozyme variation in northern populations of Asclepias exaltata (Asclepiadaceae). American Journal of Botany 85: 10911097.

Cao, X., U. Herzschuh, J. Ni, Y. Zhao and T. Böhmer. 2015. Spatial and temporal distributions of major tree taxa in eastern continental Asia during the last 22,000 years. The Holocene 25: 79-91.

Cho, W. and B. K. Chun. 2015. Restoration of the Baekdudaegan mountains in the Republic of Korea. Unasylva 245: 64-73.

Choi, Y.-K. 2004. Baekdudaegan, the central axis of the Korean Peninsula: the path toward management strategies regarding to its concepts. In Ecological Issues in a Changing World: Status, Response and Strategy. Hong, S.-K., J. A. Lee, B.-S. Ihm, A. Farina, Y. Son, E.-S. Kim and J. C. Choe (eds.), Springer, Dordrecht. Pp. 355-384.
Chung, M. Y., J. López-Pujol, Y. M. Lee, S. H. Oh and M. G. Chung. 2015. Clonal and genetic structure of Iris odaesanensis and Iris rossii (Iridaceae): insights of the Baekdudaegan Mountains as a glacial refugium for boreal and temperate plants. Plant Systematics and Evolution 301: 1397-1409.

Chung, M. Y., J. López-Pujol and M. G. Chung. 2017. The role of the Baekdudaegan (Korean Peninsula) as a major glacial refugium for plant species: A priority for conservation. Biological Conservation. http://dx.doi.org/10.1016/j.biocon.2016.11.040

Davis, M. B. 1981. Quaternary history and the stability of forest communities. In Forest Succession: Concepts and Application. West, D. C., H. H. Shugart and D. B. Botkine (eds.), Springer Verlag, Berlin. Pp. 132-153.

Delcourt, P. A. and H. R. Delcourt. 1981. Vegetation maps for eastern North America: 40,000 yr. B. P. to the present. In Geobotany II. Romans, R. C. (ed.), Plenum Press, New York. Pp. 123-165.

Dudley, N., L. Higgins-Zogib and S. Mansourian. 2005. Beyond Belief: Linking Faiths and Protected Areas to Support Biodiversity Conservation. WWF - World Wide Fund for Nature, Gland, 143 pp.

Dyer, J. M. 2006. Revisiting the deciduous forests of eastern North America. BioScience, 56: 341-352.

Edwards, G. T., J. A. Asbury and R. L. Cox. 2006. A Handbook to Appalachia: An Introduction to the Region. The University of Tennessee Press, Knoxville, TN, 336 pp.

Engler, R., V. Teplyakov and J. M. Adams. 2014. An assessment of forest cover trends in South and North Korea, from 1980 to 2010. Environmental Management 53: 194-201.

French, H. M and S. W. S. Millar. 2014. Permafrost at the time of the Last Glacial Maximum (LGM) in North America. Boreas 43: 667-677.

Godt, M. J. W., J. L. Hamrick and S. Bratton. 1995. Genetic diversity in a threatened wetland species, Helonias bullata (Liliaceae). Conservation Biology 9: 596-604.

Godt, M. J. W. and J. L. Hamrick. 1998a. Allozyme diversity in the endangered pitcher plant Sarracenia rubra spp. alabamensis (Sarraceniaceae) and its close relative S. rubra ssp. rubra. American Journal of Botany 85: 802-810.

Godt, M. J. W. and J. L. Hamrick. 1998b. Allozyme diversity in the grasses. In Population Biology in Grasses. Cheplick, G. P. (ed.), Cambridge University Press, Cambridge. Pp. 11-29.

Godt, M. J. W. and J. L. Hamrick. 2001. Genetic diversity in rare southeastern plants. Natural Areas Journal 21: 61-70.

Gonzales, E., J. L. Hamrick and S.-M. Chang. 2008. Identification of glacial refugia in south-eastern North America by phylogeographical analyses of a forest understorey plant, Trillium cuneatum. Journal of Biogeography 35: 844-852. 
Graham, A. 1999. Late Cretaceous and Cenozoic History of North American Vegetation; North of Mexico. Oxford University Press, New York, 370 pp.

Hamrick, J. L and M. J. W. Godt. 1989. Allozyme diversity in plant species. In Plant Population Genetics, Breeding and Genetic Resources. Brown, A. H. D., M. T. Clegg, A. L. Kahler and B. S. Weir (eds.), Sinauer Associates, Sunderland, MA. Pp. 43-63.

Hannan, G. L. and M. W. Orick. 2000. Isozyme diversity in Iris cristata and the threatened glacial endemic $I$. lacustris (Iridaceae). American Journal of Botany 87: 293-301.

Harrison, S. P., G. Yu, H. Takahara and I. C. Prentice. 2001. Diversity of temperate plants in east Asia. Nature 413: 129-130.

Hatcher, R. D. Jr., B. R. Bream and A. J. Merschat. 2007. Tectonic map of the southern and central Appalachians: a tale of three orogens and a complete Wilson cycle. Geological Society of America Memoirs 200: 595-632.

Hayes, P. 2010. Sustainable security in the Korean Peninsula: envisioning a northeast Asian biodiversity corridor. The Korean Journal of International Studies 8: 197-230.

HBS (Highlands Biological Station). 2016. Biodiversity of the Southern Appalachians. Retrieved Oct. 21, 2016, available from http://highlandsbiological.org/nature-center/biodiversityof-the-southern- appalachians.

Heo, H. Y., M. Hockings, W. W. Shin, H. J. Chung, N. Dudley, P. Shadie, R. Vaisanen, G. Vincent, H. Kim, S. Y. Park and S. W. Yang. 2010. Management effectiveness evaluation of Korea's protected area system. Journal of National Park Research 1: 169-179.

Hewitt, G. M. 1996. Some genetic consequences of ice ages, and their role in divergence and speciation. Biological Journal of the Linnean Society 58: 247-276.

Hewitt, G. M. 2000. The genetic legacy of the Quaternary ice ages. Nature 405: 907-913.

Hewitt, G. M. 2004. Genetic consequence of climatic oscillations in the Quaternary. Philosophical Transactions of the Royal Society of London Series B, Biological Sciences 359: 183-195.

Hope, G., A. P. Kershaw, S. van der Kaars, X. Sun, P.-M. Liew, L. E. Heusser, H. Takahara, M. McGlone, N. Miyoshi and P. T. Moss. 2004. History of vegetation and habitat change in the AustralAsian region. Quaternary International 118-119: 103-126.

Hu, F. S., A. Hampe and R. J. Petit. 2009. Paleoecology meets genetics: deciphering past vegetational dynamics. Frontiers in Ecology and the Environment 7: 371-379.

IUCN (International Union for Conservation of Nature). 2012. Resolutions and Recommendations. World Conservation Congress, Jeju, Republic of Korea, 6-15 September 2012. IUCN, Gland, $251 \mathrm{pp}$.
Jackson, S. T., R. S. Webb, K. H. Anderson, J. T. Overpeck, T. Webb III, J. W. Williams and B. C. S. Hansen. 2000. Vegetation and environment in Eastern North America during the Last Glacial Maximum. Quaternary Science Reviews 19: 489-508.

Joyner, L. 2016. Hiking through History: Civil War Sites on the Appalachian Trail. Appalachian Trail Conservancy, Harpers Ferry, 176 pp.

Jung, H.-C., D.-K. Lee, S.-W. Jeon and W.-K. Song. 2005. Analysis of deforestation patterns in the Baekdudaegan preservation area using land cover classification and change detection techniques: the feasibility of restoration. Landscape and Ecological Engineering 1: 177-190.

Kang, H.-S., S.-Y. Shin and H.-J. Whang. 2010. Are the conservation areas sufficient to conserve endangered plant species in Korea? Journal of Ecology and Field Biology 33: 377-389.

Kang, S. and W. Choi. 2014. Forest cover changes in North Korea since the 1980s. Regional Environmental Change 14: 347354.

Kennedy, A. H. and G. L. Walker. 2007. The population genetic structure of the showy lady's slipper orchid (Cypripedium reginae Walter) in its glaciated and unglaciated ranges. Castanea 72: 248-261.

Kim, K. O., S. H. Hong, Y. H. Lee, C. S. Na, B. H. Kang and Y. Son. 2009. Taxonomic status of endemic plants in Korea. Journal of Ecology and Field Biology 32: 277-293.

Kim, R. E. and Ali, S. H. 2016. Green diplomacy: an opportunity for peace-building? Environmental Policy and Law 46: 86-96.

Kim, Y.-S. 2006. Conservation of plant diversity in Korea. Landscape and Ecological Engineering 2: 163-170.

Kong, W.-S. and P. Watts. 1993. The Plant Geography of Korea with an Emphasis on the Alpine Zones. Kluwer Academic Publishers, Dordrecht, 229 pp.

Kwon, T.-H. and J.-W. Lee. 2003. Trail deterioration on the ridge of the Baekdudaegan: a case of the trail between Manbokdae and Bokseongijae. Korean Journal of Environment and Ecology 16: 465-474.

Kwon, T.-H., J.-W. Lee and D.-W. Kim. 2004. Trail deterioration and managerial strategy on the ridge of the Baekdudaegan: a case of the trail between Namdeogyusan and Sosagogae. Korean Journal of Environment and Ecology 18: 175-183.

Lee, C.-B., J.-H. Chun, H.-K. Song and H.-J. Cho. 2013. Altitudinal patterns of plant species richness on the Baekdudaegan Mountains, South Korea: mid-domain effect, area, climate, and Rapoport's rule. Ecological Research 28: 67-79.

Lee, J.-H., M.-J. Lee and G.-G. Lee. 2015. National level assessment of biodiversity importance: focusing on South Korea. KSCE Journal of Civil Engineering 19: 46-62. 
Lennon, J. 2006. Cultural heritage management. In Managing Protected Areas: A Global Guide. Lockwood, M., G. L. Worboys and A. Kothari (eds.), Earthscan, London. Pp. 448-473.

Lewis, P. O. and D. J. Crawford. 1995. Pleistocene refugium endemics exhibit greater allozyme diversity than widespread congeners in the genus Polygonella (Polygonaceae). American Journal of Botany 82: 141-149.

Lillard, D. E. 2002. Appalachian Trail Names: Origins of Place Names along the AT. Stackpole Books, Mechanicsburg, 160 pp.

Lim, D.-O. 2003. Vascular plants of mountain ridge from Cheonwangbong-Hyangjeokbong section in the Baekdudaegan. Korean Journal of Environment and Ecology 16: 359-386. (in Korean with English abstract)

Liu, J.-Q., Y.-S. Sun, X.-J. Ge, L.-M. Gao and Y.-X. Qiu. 2012. Phylogeographic studies of plants in China: advances in the past and directions in the future. Journal of Systematics and Evolution 50: 267-275.

Marshall, I. 1998. Story Line: Exploring the Literature of the Appalachian Trail. University Press of Virginia, Charlottesville and London, $284 \mathrm{pp}$.

Mason, D. and M.-Y. Chung. 2008. The burgeoning of the Baekdu-daegan trail into a new religious-pilgrimage tourism asset of South Korea. Journal of Tourism and Leisure Research 20: 425-441.

Mason, D. A. 2011a. The Korean Forest Culture of the Baekdu Daegan. Korea Forest Service, Seoul.

Mason, D. A. 2011b. Republic of Korea: Baekdu-daegan Trail. In Religious Tourism in Asia and the Pacific. Xu, F. (ed.), The World Tourism Organization, Madrid. Pp. 207-220.

McKinnon, J. and Y. Xie. 2008. Regional Action Plan for the Protected Areas of East Asia. 2006-2010. IUCN, Bangkok, 82 pp.

Médail, F. and K. Diadema. 2009. Glacial refugia influence plant diversity patterns in the Mediterranean Basin. Journal of Biogeography 36: 1333-1345.

Miller, K. and H. Kim. 2010. Ecological Corridors: Legal Framework for the Baekdu Daegan Mountain System (South Korea). IUCN, Gland, 13 pp.

Mokhova, L., P. Tarasov, V. Bazarova and M. Klimin. 2009. Quantitative biome reconstruction using modern and late Quaternary pollen data from the southern part of the Russian Far East. Quaternary Science Reviews 28: 2913-2926.

Nei, M. 1973. Analysis of gene diversity in subdivided populations. Proceedings of the National Academy of Sciences of the United States of America 70: 3321-3323.

Ono, Y., T. Aoki, H. Hasegawa and L. Dali. 2005. Mountain glaciation in Japan and Taiwan at the global Last Glacial Maximum. Quaternary International 138-139: 79-92.
Petit-Maire, N. and P. Bouysse. 2000. Geological records of the recent past, a key to the near future world environments. Episodes 23: 230-246.

Prentice, I. C., S. P. Harrison and P. J. Bartlein. 2011. Global vegetation and terrestrial carbon cycle changes after the last ice age. New Phytologist 189: 988-998.

Provan, J. and K. D. Bennett. 2008. Phylogeographic insights into cryptic glacial refugia. Trends in Ecology and Evolution 23: $564-571$.

Qiu, Y.-X., C.-X. Fu and H. P. Comes. 2011. Plant molecular phylogeography in China and adjacent regions: tracing the genetic imprints of Quaternary climate and environmental change in the world's most diverse temperate flora. Molecular Phylogenetics and Evolution 59: 225-244.

Rankin, D. W. 1975. The continental margin of eastern North America in the Southern Appalachians: the opening and closing of the Proto-Atlantic Ocean. American Journal of Science 275-A: 298-336.

Raven, P. H. 2013. Engaging North Korea through biodiversity protection. Science and Diplomacy 2. Retrieved Oct. 21, 2016, available from http://www.sciencediplomacy.org/perspective/ 2013/engaging-north-korea-through-biodiversity-protection.

Redick, K. 2009. Wilderness as axis mundi: spiritual journeys on the Appalachian Trail. In Symbolic Landscapes. Backhaus G. and J. Murungi (eds.), Springer, Dordrecht. Pp. 65-90.

Rull, V. 2009. Microrefugia. Journal of Biogeography 36: 481-484. Sawagaki, T. and T. Aoki. 2011. Late Quaternary glaciations in Japan. In Quaternary Glaciations: Extent and Chronology. Ehlers, J., P. L. Gibbard and P. D. Hughes (eds.), Elsevier, Amsterdam and Oxford. Pp. 1013-1021.

Schaaf, T. and C. Lee. 2006. Conserving Cultural and Biological Diversity: The Role of Sacred Natural Sites and Cultural Landscapes. United Nations Educational, Scientific and Cultural Organization (UNESCO), Paris 341 pp.

Soltis, D. E., A. B. Morris, J. S. McLachlan, P. S. Manos and P. S. Soltis. 2006. Comparative phylogeography of unglaciated eastern North America. Molecular Ecology 15: 4261-4293.

Stewart, J. R., A. M. Lister, I. Barnes and L. Dalén. 2010. Refugia revisited: individualistic responses of species in space and time. Proceedings of the Royal Society B: Biological Sciences 277: 661-671.

Stone, J. L., P. A. Crystal, E. E. Devlin, R. H. Downer and D. S. Cameron. 2012. Highest genetic diversity at the northern range limit of the rare orchid Isotria medeoloides. Heredity 109: 215-221.

Swenson N. G. and D. J. Howard. 2005. Clustering of contact zones, hybrid zones, and phylogeographic breaks in North America. The American Naturalist 166: 581-591. 
Velichko, A. and I. Spasskaya. 2002. Climatic change and the development of landscapes. In The Physical Geography of Northern Eurasia: Russia and Neighbouring States. Shahgedanova, M. (ed.), Oxford University Press, Oxford. Pp. $36-69$.

Verschuuren, B., R. Wild, J. A. McNeely and G. Oviedo. 2010. Sacred Natural Sites: Conserving Nature and Culture. Earthscan, London, 310 pp.

Wallace, L. E. and M. A. Case. 2000. Contrasting allozyme diversity between northern and southern populations of Cypripedium parviflorum (Orchidaceae): implications for Pleistocene refugia and taxonomic boundaries. Systematic Botany 25: 281-296.

Walter, R. and B. K. Epperson. 2001. Geographic pattern of genetic variation in Pinus resinosa: area of greatest diversity is not the origin of postglacial populations. Molecular Ecology 10: 103-111.

Wang, Z.-F., J. L. Hamrick and M. J. W. Godt. 2004. High genetic diversity in Sarracenia leucophylla (Sarraceniaceae), a carnivorous wetland herb. Journal of Heredity 95: 234-243.

Wen, J. 1999. Evolution of eastern Asian and eastern North American disjunct distributions in flowering plants. Annual Review of Ecology and Systematics 30: 421-455.

Whitkus, R., F. A. Bryan, D. H. Les and L. E. Tyrell. 1987. Genetic structure in a heterocyanic population of Trillium sessile (Liliaceae). Plant Species Biology 2: 67-73.
Williams, J. W., T. Web III, P. H. Richard and P. Newby. 2000. Late Quaternary biomes of Canada and the eastern United States. Journal of Biogeography 27: 585-607.

Woillez, M.-N., M. Kageyama, G. Krinner, N. de Noblet-Ducoudré, N. Viovy and M. Mancip. 2011. Impact of $\mathrm{CO}_{2}$ and climate on the Last Glacial Maximum vegetation: results from the ORCHIDEE/IPSL models. Climate of the Past 7: 557577.

Woodcock, D. W. and P. V. Wells. 1990. Full-glacial summer temperatures in eastern North America as inferred from Wisconsinan vegetational zonation. Palaeogeography, Palaeoclimatology, Palaeoecology 79: 305-312.

Yi, S. 2011. Holocene vegetation responses to East Asian monsoonal changes in South Korea. In Climate Change: Geophysical Foundations and Ecological Effects. Blanco, J. and H. Kheradmand (eds.), InTech, Rijeka. Pp. 157-178.

Zheng, Y. Q., Z. C. Qian, H. R. He, H. P. Liu, X. M. Zeng and G. Yu. 2007. Simulations of water resource environmental changes in China during the last 20,000 years by a regional climate model. Global and Planetary Change 55: 284-300.

Zhou, S., J. Li, J. Zhao, J. Wang and J. Zheng. 2011. Quaternary glaciations: extent and chronology in China. In Quaternary Glaciations: Extent and Chronology. Ehlers, J., P. L. Gibbard and P. D. Hughes (eds.), Elsevier, Amsterdam and Oxford. Pp. 981-1002. 